\title{
Distal Bile Duct Cancer pTis TNM Finding v7
}

National Cancer Institute

\section{Source}

National Cancer Institute. Distal Bile Duct Cancer pT is TNM Finding v7. NCI Thesaurus.

Code C90248.

Distal bile duct cancer with a finding of carcinoma in situ. (from AJCC 7th Ed.) 